\title{
SHORT PAPER \\ Presence of Legionellaceae in warm water supplies and typing of strains by polymerase chain reaction
}

\author{
B. ZIETZ*, J. WIESE, F. BRENGELMANN AND H. DUNKELBERG \\ Medical Institute for General Hygiene and Environmental Health, University of Göttingen, Windausweg 2, \\ D-37073 Göttingen, Germany
}

(Accepted 18 October 2000)

\section{SUMMARY}

Outbreaks of Legionnaire's disease present a public health challenge especially because fatal outcomes still remain frequent. The aim of this study was to describe the abundance and epidemiology of Legionellaceae in the human-made environment. Water was sampled from hotwater taps in private and public buildings across the area of Göttingen, Germany, including distant suburbs. Following isolation, we used polymerase chain reaction in order to generate strain specific banding profiles of legionella isolates. In total, 70 buildings were examined. Of these $18(26 \%)$ had the bacterium in at least one water sample. Legionella pneumophila serogroups 1, 4, 5 and 6 could be identified in the water samples. Most of the buildings were colonized solely by one distinct strain, as proven by PCR. In three cases equal patterns were found in separate buildings. There were two buildings in this study where isolates with different serogroups were found at the same time.

Legionella pneumophila were first recognized as the aetiological agent of Legionnaire's disease in 1977 following an epidemic of acute pneumonia at an American Legion convention in Philadelphia [1, 2]. Since that time many different serogroups and related species of this bacterium have been detected [3, 4]. Known as especially relevant for transmission are contaminated warm water supplies, cooling towers, evaporative condensers, whirlpool spas and respiratory therapy equipment [5]. Surveys of lakes, ponds, streams, and soils have indicated that this bacterium is also a common inhabitant of natural waters [6]. Because of the widespread distribution several methods have been used to discriminate between different strains of Legionella pneumophila. Most frequently used is typing with monoclonal antibodies [7], but polymerase chain reaction methods [8], and analysis of restriction fragment length polymorphisms [9] are also common.

* Author for correspondence.
Recent information about the frequency as well as the distribution of different or equal legionella strains in the water systems of a restricted area in Germany are scarce and may differ from other parts of the country or the world. Thus, the aim of this study was to describe the abundance and epidemiology of Legionellaceae in water systems of different buildings in a German town in Lower Saxony. Special interest was directed to the presence of distinct strains in hospitals and old people's homes in contrast to other buildings. This was done to evaluate the question whether nosocomial infections can be securely differentiated from community-acquired types using a newly developed PCR analysis to further differentiate between strains on the serogroup level.

Water samples. Water was sampled from private and public buildings between February and September 1999 in Göttingen and area, Germany. In private buildings water was taken in the bath room from the hot-water taps. Water samples from public buildings were obtained by turning on the hot-water 
tap (mostly from showers heads) and taking the first water and then taking a second portion when the water reached the highest temperature. In total 129 samples from 70 buildings were collected.

Water supply. All sampled buildings were supplied by the water plant of Göttingen (Stadtwerke Göttingen AG). The distribution system could be divided into three main pressure zones according to different elevations of the city and several small higher or more distant zones. Water was supplied to the lowest zone by three facilities that combine water from a transport pipe from the Harz Mountains (about $80 \%$ ) and their local well [10]. Out of this zone water was pumped up to the other zones.

Bacteriological assay. Water samples (11 volume) were filtered through $0.45 \mu \mathrm{m}$ pore-size cellulosemixed ester filters with a diameter of $50 \mathrm{~mm}$ (Schleicher and Schuell, Dassel, Germany) using a vacuum pump according to Pabst et al. [11] and the German federal health agency [12]. Then $10 \mathrm{ml}$ of a $\mathrm{KCl} / \mathrm{HCl}$ buffer $(0 \cdot 2 \mathrm{M}$, adjusted to $\mathrm{pH} 2 \cdot 2)$ was poured onto the filter and removed again after $5 \mathrm{~min}$. The filters were placed on a MWY agar plate (following Wadowski and Yee, modified by Edelstein, supplied by Oxoid, Wesel, Germany) and incubated at $37^{\circ} \mathrm{C}$ in a humidified atmosphere (plastic bag) for 7 days and examined daily. Additionally $1 \mathrm{ml}$ of water was added to $1 \mathrm{ml}$ of a $\mathrm{KCl} / \mathrm{HCl}$ buffer and after 5 min $0.5 \mathrm{ml}$ of the solution was used to inoculate the surface of the MWY agar. This was done in duplicate.

Colonies that morphologically matched legionella colonies were subcultured onto blood and MWY agar. Representative colonies (1-2) of those that failed to grow on blood agar were examined by direct fluorescent antibody technique using $L$. pneumophila serogroups 1-6 rabbit globulin and a combined $L$. bozemanii, L. dumofii, L. gormanii, L. jordanis, L. longb. $1+2$, L. micdadei rabbit globulin supplied by Viramed, Planegg/Steinkirchen, Germany and $L$. pneumophila serogroups 1-14 monoclonal antibodies (mouse) supplied by Pro-Lab Diagnostics (Mast Diagnostica), Reinfeld, Germany. Isolates were stored at $-70{ }^{\circ} \mathrm{C}$ (Microbank, Mast Diagnostica).

Polymerase chain reaction. To identify different strains of legionella we used different primers to amplify DNA fragments in crude bacterial lysates to generate banding profiles. The used method was based on a development of Wiese et al. (unpublished results). The stored isolates were cultured on MWY agar plates at $37^{\circ} \mathrm{C}$ for 3 days. Next, colonies of each isolate were picked from the plates and suspended in
$200 \mu \mathrm{l}$ of $5 \%$ Chelex 100 (Biorad, Münden, Germany), vortexed for $15 \mathrm{sec}$ and incubated in a heating block for $30 \mathrm{~min}$ at $99^{\circ} \mathrm{C}$. After centrifugation at $14500 \mathrm{~g}$ for $5 \mathrm{~min}$ TE buffer (20-fold concentration) was added to the supernatent. These crude lysates were stored at $-20{ }^{\circ} \mathrm{C}$ and used in PCR reactions after adjusting them to a DNA concentration of $10 \mu \mathrm{g} / \mathrm{ml}$ with TE buffer (10 mM Tris-HCl, pH $8.0 ; 1 \mathrm{~mm}$ EDTA, pH 8.0). DNA concentrations in the lysates were determined by UV spectroscopy (wavelength $260 \mathrm{~nm}$ ). PCR reactions were carried out in a final volume of $25 \mu \mathrm{l}$ containing $5 \mu \mathrm{l}$ sample DNA, $2 \cdot 5 \mu \mathrm{l}$ primer $(0.01 \mathrm{~nm} / \mu \mathrm{l})$ and $17.5 \mu 1 \mathrm{H}_{2} \mathrm{O}$. This mixture was added to 'Ready To Go Analysis Beads' (Pharmacia Biotech Europe, Freiburg) each containing Ampli-Taq DNA polymerase, $0.4 \mathrm{~mm}$ deoxynucleotide triphosphates, $2.5 \mu \mathrm{g}$ BSA and buffer (3 mM $\mathrm{MgCl}_{2}, 30 \mathrm{~mm} \mathrm{KCl}, 10 \mathrm{~mm}$ Tris [pH 8.3]).

Primers were ERIC2 (5'-AAGTAAGTGACTGGGGTGAGCG-3', [8]) and a combination of Lpm-1 (5'-GGTGACTGCGGCTGTTATGG-3') and Lpm2 (5'-GGCCAATAGGTCCGCCAACG-3') [13]. ERIC2 is an enterobacterial repetitive intergenic consensus motif. Lpm-1 and Lpm-2 are part of the macrophage infectivity potentiator (mip) gene of legionella. The primers were synthesized and cleaned by HPLC by Biometra (Göttingen, Germany).

Thermal cycling was carried out in a Crocodile III thermal cycler (Appligene Oncor, Heidelberg, Germany). After an initial denaturation at $94{ }^{\circ} \mathrm{C}$ for 5 min, 45 cycles of $60 \mathrm{~s}$ at $94{ }^{\circ} \mathrm{C}, 110 \mathrm{~s}$ ramp to $36^{\circ} \mathrm{C}, 60$ s at $36^{\circ} \mathrm{C}$ and $120 \mathrm{~s}$ at $72{ }^{\circ} \mathrm{C}$. This was followed by 1 cycle of $72{ }^{\circ} \mathrm{C}$ for $10 \mathrm{~min}$.

The following reference strains were used as control: L. pneumophila ATCC 33152 (serogroup 1), ATCC 33156 (serogroup 4), ATCC 33216 (serogroup 5) and ATCC 33215 (serogroup 6) for banding patterns.

Gel electrophoresis. Gels were stained by adding ethidium bromide to the agarose gel and banding patterns were visualized under ultraviolet light. A $100 \mathrm{bp}$ ladder (Pharmacia Biotech, Freiburg, Germany) was utilized as a size marker.

Band patterns were compared visually. Isolates of a serogroup were considered to have the same PCR type when the patterns obtained with both primers were indistinguishable. Very weak bands (not apparent on the photographs and/or not detected reproducibly) were not taken into account. In doubtful cases, the amplifications were repeated, and the patterns were compared after comigration on the same agarose gel. 
Table 1. Detected Legionellaceae in different types of buildings

\begin{tabular}{lllll}
\hline \hline & $\begin{array}{l}\text { Number of } \\
\text { tested } \\
\text { buildings }\end{array}$ & $\begin{array}{l}\text { Buildings with at } \\
\text { least one sample } \\
\text { containing } \\
\text { Legionellaceae }\end{array}$ & $\begin{array}{l}\text { Range of colony } \\
\text { forming units } \\
\text { (c.f.u.)/1 }\end{array}$ & $\begin{array}{l}\text { Found } \\
\text { serogroups (all } \\
\text { isolates } L . \\
\text { pneumophila) }\end{array}$ \\
\hline Type of building & 24 & $5(21 \%)$ & $22-5000$ & $1,4,5,6$ \\
Sports halls and swimming baths & 19 & $5(26 \%)$ & $3-8000$ & $1,4,6$ \\
University buildings & 8 & $5(63 \%)$ & $4000-78000$ & $1,4,6$ \\
Hospitals and old people's homes & 4 & $2(50 \%)$ & $5-68$ & 1,5 \\
Halls of residence & 4 & $0(0 \%)$ & - & 1 \\
Hotels & 11 & $1(9 \%)$ & 2000 & $1,4,5,6$ \\
Other buildings & $18(26 \%)$ & $3-78000$ & \\
Total & 70 & &
\end{tabular}

Legionella contamination: Out of 70 tested buildings $18(26 \%)$ contained Legionellaceae in at least one sample. Referring to the types of the buildings the results are depicted in Table 1. It is remarkable that hospitals and old people's homes used by a very sensitive population group had the highest rate of contamination among all tested buildings. Though it has to be taken into account that the tested number of these buildings was limited and the results thus may not be representative.

The distribution of the maximum found colonyforming units (c.f.u.) of legionella for all buildings was as follows. Legionella not detectable in 52 buildings; $1-100$ c.f.u./1 in 7 buildings; $101-1000$ c.f.u./1 in 1 building; 1001-10000 c.f.u./1 in 6 buildings and 10001-100000 in 4 buildings. The overall trend was that the larger the buildings plumbing had been, the more samples were positive for legionella and the more bacteria could be found. The highest detected concentration of bacteria was 78000 c.f.u./1. Temperatures of contaminated second water samples were in many cases below $45^{\circ} \mathrm{C}$ (Table 2). Also in Lower Saxony, Germany, Habicht and Müller [14] found that $70 \%$ of the 103 hospitals and $18 \%$ of the 62 hotels investigated were positive for legionella. These findings are similar to our results testing only one supply area more than 10 years later. Boschek et al. [15] were able to culture Legionellaceae in warm water from 11 out of 12 sampled hospitals in a German town. In Canada a frequency for legionella contaminated hospitals of $32 \%$ was found [16]. It has to be taken into account that methods used vary between these studies. A high constancy (regular detection, only a few minor genetical changes) of legionella colonization was found by Lück et al. [17] in a hospital connected with a ring pipe warm water system over 7 years. It is important to know that hospitals and old people's homes used by a risk group for infections frequently had a high rate of contamination including this study.

Detected serogroups. Only Legionella pneumophila serogroups 1, 4, 5 and 6 could be identified in the water samples. No other Legionella species was found. The distribution of the isolates among the serogroups is given in Table 2. There were two buildings in this study where isolates with different serogroups were found at the same time (hospital/old people's home E and F). Four isolates of serogroup 1 (G6, G10, G12, G13) were reanalysed at the University of Dresden (Dr P. C. Lück) for their classification into serogroups. This study was more concentrated on the epidemiology of different contaminated buildings than on detecting a minor colonization with distinct strains in the same building. Because only 1-3 colonies per sample were analysed with direct fluorescent antibody technique it is possible that a (minor) co-colonization with different serogroups may have been overlooked.

Referring to the frequency of serogroups of $L$. pneumophila the results of this study were similar to results of other studies $[14,15,18]$. In contrast to this some authors found non-pneumophila strains to be present also in the general environment $[6,19]$. This may be due to the existence of different legionella strains in various habitats or due to the use of different selective media. In a comparative test Ta et al. [20] were only able to detect non-pneumophila species in water samples with culture on BCYE medium. Nonpneumophila species grew poorly on all selective media used. In other studies our laboratory has cultured legionella from water also using $\mathrm{BCYE} \alpha$ combined with BMPA supplement parallel to the method described above. We have never isolated a non-pneumophila species from our water samples, but non-pneumophila reference strains can be grown on 
Table 2. Source and PCR pattern of legionella isolates used in this study

\begin{tabular}{|c|c|c|c|c|}
\hline Designation & Source & Date of sampling & Serogroup & PCR pattern \\
\hline G1 & Hospital/old people's home F, 2nd water & 15 Mar. 1999 & 1 & $1 \mathrm{~A}$ \\
\hline G2 & Hall of residence $C, 2$ nd water & 17 Feb. 1999 & 1 & 1B \\
\hline G3 & Sports hall/swimming bath I, 1st water & 9 Jul. 1999 & 1 & $1 \mathrm{C}$ \\
\hline G4 & Sports hall/swimming bath I, 2 nd water, $36^{\circ} \mathrm{C}$ & 9 Jul. 1999 & 1 & $1 \mathrm{C}$ \\
\hline G5 & Sports hall/swimming bath $\mathrm{X}, 1$ st water & 23 Jul. 1999 & 1 & 1D \\
\hline G6 & University building $\mathrm{H}$, 2nd water, $51^{\circ} \mathrm{C}$ & 3 Sep. 1999 & 1 & $1 \mathrm{E}$ \\
\hline G7 & Private/company building J, 1st water & 9 Sep. 1999 & 1 & $1 \mathrm{~A}$ \\
\hline G8 & Hospital/old people's home $\mathrm{H}$, 1st water & 9 Sep. 1999 & 1 & $1 \mathrm{~F}$ \\
\hline G9 & Hospital/old people's home $\mathrm{H}, 2$ nd water, $42^{\circ} \mathrm{C}$ & 9 Sep. 1999 & 1 & $1 \mathrm{~F}$ \\
\hline G10 & Hospital/old people's home E, 2nd water, $48^{\circ} \mathrm{C}$ & 15 Sep. 1999 & 1 & $1 \mathrm{~A}$ \\
\hline G11 & Hospital/old people's home E, 2 nd water, $36{ }^{\circ} \mathrm{C}$ & 15 Sep. 1999 & 1 & $1 \mathrm{~A}$ \\
\hline G12 & Hospital/old people's home E, 1st water & 15 Sep. 1999 & 1 & $1 \mathrm{~A}$ \\
\hline G13 & Hospital/old people's home E, 2nd water, $40^{\circ} \mathrm{C}$ & 15 Sep. 1999 & 1 & $1 \mathrm{~A}$ \\
\hline G14 & Sports hall/swimming bath V, 1st water & 23 Jul. 1999 & 4 & $4 \mathrm{~A}$ \\
\hline G15 & Hospital/old people's home G, 1st water & 9 Sep. 1999 & 4 & 4B \\
\hline G16 & Hospital/old people's home $\mathrm{G}, 2$ nd water, $46^{\circ} \mathrm{C}$ & 9 Sep. 1999 & 4 & 4B \\
\hline G17 & Hospital/old people's home $\mathrm{G}, 2$ nd water, $40^{\circ} \mathrm{C}$ & 9 Sep. 1999 & 4 & 4B \\
\hline G18 & University building $\mathrm{M}, 2$ nd water, $49^{\circ} \mathrm{C}$ & 10 Sep. 1999 & 4 & $4 \mathrm{C}$ \\
\hline G19 & Hospital/old people's home A, 1st water & 11 Sep. 1999 & 4 & (4B) cf. to text \\
\hline G20 & Hospital/old people's home E, 1st water & 15 Sep. 1999 & 4 & $4 \mathrm{D}$ \\
\hline G21 & Hospital/old people's home E, 1st water & 15 Sep. 1999 & 4 & $4 \mathrm{E}$ \\
\hline G22 & Hall of residence A, 2nd water & 15 Mar. 1999 & 5 & $5 \mathrm{~A}$ \\
\hline G23 & Sports hall/swimming bath A, 2 nd water, $36{ }^{\circ} \mathrm{C}$ & 25 Jun. 1999 & 5 & $5 \mathrm{~B}$ \\
\hline G24 & $\begin{array}{l}\text { Hospital/old people's home F, 2nd water, } \\
\text { two isolates cultured: G24a and G24b }\end{array}$ & 15 Mar. 1999 & 6 & $6 \mathrm{~A}$ \\
\hline G25 & Sports hall/swimming bath $\mathrm{O}, 1$ st water & 15 Jul. 1999 & 6 & 6B \\
\hline G26 & Sports hall/swimming bath $\mathrm{O}, 2$ nd water, $31{ }^{\circ} \mathrm{C}$ & 15 Jul. 1999 & 6 & $6 \mathrm{~B}$ \\
\hline G27 & University building B, 2nd water, $51^{\circ} \mathrm{C}$ & 31 Aug. 1999 & 6 & $6 \mathrm{C}$ \\
\hline G28 & University building E, 1st water & 31 Aug. 1999 & 6 & $6 \mathrm{C}$ \\
\hline G29 & University building E, 2 nd water, $46^{\circ} \mathrm{C}$ & 31 Aug. 1999 & 6 & $6 \mathrm{C}$ \\
\hline G30 & University building I, 2nd water, $47^{\circ} \mathrm{C}$ & 3 Sep. 1999 & 6 & $6 \mathrm{D}$ \\
\hline $\mathrm{X} 1$ & Hospital/old people's home E, cold water installation & 6 Aug. 1997 & 1 & $1 \mathrm{~A}$ \\
\hline $\mathrm{X} 2$ & Hospital/old people's home E, cold water installation & 7 Oct. 1996 & 1 & $1 \mathrm{~A}$ \\
\hline $\mathrm{X} 3$ & Hospital/old people's home E, cold water installation & 6 Aug. 1997 & 5 & $5 \mathrm{C}$ \\
\hline X4 & Hospital/old people's home E, cold water installation & 25 Aug. 1997 & 5 & $5 \mathrm{D}$ \\
\hline R1 & Reference strain ATCC 33152 & & 1 & $1 \mathrm{R}$ \\
\hline R2 & Reference strain ATCC 33156 & & 4 & $4 \mathrm{R}$ \\
\hline R3 & Reference strain ATCC 33216 & & 5 & $5 \mathrm{R}$ \\
\hline R4 & Reference strain ATCC 33215 & & 6 & $6 \mathrm{R}$ \\
\hline
\end{tabular}

our media. At present no official external quality assurance programme for legionella exists in Germany.

Results concerning the number of colony forming units found in Göttingen were similar to other studies $[14,15]$.

PCR patterns: In total 31 isolates have been stored and typed with PCR based techniques (Table 2). None of our isolates produced a pattern identical to the reference strains. In the following the reference strains were not mentioned as separate banding types any more.
Isolates of serogroup 1 sampled in the area of Göttingen showed six different banding patterns. Six isolates (G1, G7, G10-G13) of this serogroup had an identical profile. These were cultured from water sampled in three different buildings, located in two different supply zones. Two additional samples (X1, $\mathrm{X} 2$ ) from one of these buildings that were found about 2 years prior to this study had an identical pattern. Banding profiles of serogroup 4 isolates can be grouped in five patterns. There was one building that was colonized with two strains of serogroup 4 differing in PCR analysis (G20, G21). These samples were 
found in hospital/old people's home $\mathrm{E}$ in water sampled on the same day in different parts of the building. Four isolates (G15-G17, G19) of this serogroup produced an identical profile. They were cultured from two hospitals/old people's homes with a distance of more than 1000 metres and located in separate supply zones. Because there is a very fine additional banding in the isolate (G19) of one building that could be reproduced in a second PCR test it is possible that these buildings also have different strains.

The two isolates (G22, G23) of serogroup 5 had different banding patterns. Two additional samples $(\mathrm{X} 3, \mathrm{X} 4)$ from a hospital in Göttingen that were found about 2 years prior to this study also had different banding characteristics.

Isolates of serogroup 6 gave four different banding patterns. Three isolates (G27, G28, G29) that showed identical patterns were found in two separate university buildings with a distance of about 500 metres and were supplied by the same pressure zone. A different pattern of serogroup 6 was found in an other building of the same complex (G30). It can be summarized that only in three cases identical patterns were found in separate buildings in Göttingen. In two cases the same banding pattern was produced by samples from two different buildings and in one case isolates cultured from water samples from three buildings had identical patterns. Two isolates with equal bandings came from samples of the same building in four cases. In two cases different strains were found in the same buildings at the same time.

Except for one (G30, discrimination by ERIC2) isolate both used primer Eric2 and the combination of Lpm-1 and Lpm-2 were able to differentiate between the mentioned strains.

Repeating the analysis of some isolates and reference strains over several years with different lots of reagents no changes in the resulting gel patterns were observed. However, there are reports that changes in equipment and reagents may result in a loss of reproducibility in DNA fingerprinting methods $[21,22]$. To ensure reproducibility of this PCR testing all reagents and primers were used from identical lots and equipment was not changed during the study. Testing a set of 10 serogroup 1 reference strains primer pair Lpm-1/Lpm-2 were able to distinguish between 9 strains and primer ERIC2 was able to distinguish between 8 strains (data not shown). Bansal and McDonell [23] used PCR-based DNA fingerprinting technique with a combination of two random primers (double RAPD) to study its discriminatory ability with 67 well-defined legionella reference strains (representing 39 species) and 120 outbreak-related environmental and clinical isolates. For reference strains they obtained a unique strain-specific array of fragments for each species, serovar, and subtype. The band definition was adequate for confident visual comparison of the fingerprints located on the same or on different agarose gels. They concluded that this method was low-cost but sufficiently powerful and reliable to type individual strains. Other authors that made a methodological comparison of DNA fingerprinting and other epidemiological typing methods mostly found comparable discriminatory ability between the different methods [24-27].

The isolates from 18 buildings found in this study could be classified into four serogroups of $L$. pneumophila. The variety of serogroups could further be divided in many more strains using PCR method. Only in three cases equal patterns were found in separate buildings. In one case the presence of equal strains could be shown for a hospital, an old people's home and a private building. This is an important finding with regard to the question whether an infection is nosocomial or community-acquired.

No association of serogroups or identical strains and water supply zones was found. So the exact evolution and origin of these populations remains unclear.

The main conclusion of our study is that there exists a great diversity of legionella strains below the serogroup level detectable by PCR analysis.

The high frequency of legionella contamination in hospitals and old people's homes (revealed not only by this study) shows that regular controls and protection measurements can be an important part of prevention against Legionnaire's disease and Pontiac fever.

\section{ACKNOWLEDGEMENTS}

The authors thank J. Ebert, B. Gerhart, Dr S. Kevekordes and M. Leister for their technical support and Dr S. Wagner for reviewing the manuscript.

\section{REFERENCES}

1. Fraser DW, Tsai TR, Orenstein W, et al. Field Investigation team. Legionnaires' disease: description of an epidemic of pneumonia. N Engl J Med 1977; 297: 1189-97. 
2. McDade JE, Shepard CC, Fraser DW, et al Legionnaires' disease: isolation of a bacterium and demonstration of its role in other respiratory disease. N Engl J Med 1977; 297: 1197-203.

3. Benson RF, Fields BS. Classification of the genus Legionella. Sem Resp Inf 1998; 13: 90-9.

4. Riffard S, Vandenesch F, Reyrolle M, Etienne J. Distribution of mip-related sequences in 39 species (48 serogroups) of Legionellaceae. Epidemiol Infect 1996; 117, 501-6.

5. Breiman RF, Butler JC. Legionnaires' disease: clinical, epidemiological, and public health perspectives. Sem Resp Inf 1998; 13: 84-9.

6. Fliermans CB. Ecology of Legionella: From data to knowledge with a little wisdom. Microb Ecol 1996; 32: 203-28.

7. Joly JR, McKinney RM, Tobin JO, et al. Development of a standardized subgrouping scheme for Legionella pneumophila serogroup 1 using monoclonal antibodies. J Clin Microbiol 1986; 23: 768-71.

8. van Belkum A, Struelens M, Quint W. Typing of Legionella pneumophila strains by polymerase chain reaction-mediated DNA fingerprinting. J Clin Microbiol 1993; 31: 2198-200.

9. Saunders NA, Harrison TG, Haththotuwa A, Kachwalla N, Taylor AG. A method for typing strains of Legionella pneumophila serogroup 1 by analysis of restriction fragment length polymorphisms. J Med Microbiol 1990; 31: 45-55.

10. Schumacher PG, Wagner I, Kuch A. Die Trinkwasserversorgung von Göttingen mit Mischwasser. Erfahrungen über den Einfluß der Wasserqualität und von Inhibitoren auf Korrosion im Rohrnetz. gwf Wasser/ Abwasser 1988; 129: 146-52.

11. Pabst U, Demuth J, Gebel $T$, Dunkelberg $H$. Etablierung einer Methode zum Nachweis der Assoziation von Legionella sp. mit Amoeba sp. mittels Polymerasekettenreaktion. Zbl Hyg Umweltmed 1997; 199: 568-77.

12. Bundesgesundheitsamt. Mitteilung des Bundesgesundheitsamtes über den Nachweis von Legionellen in erwärmten Trinkwasser. Bundesgeshbl 1993; 36: 162.

13. Jaulhac B, Nowicki M, Bornstein N, et al. Detection of Legionella spp. in bronchoalveolar lavage fluids by DNA amplification. J Clin Microbiol 1992; 30: 920-4.

14. Habicht W, Müller HE. Occurrence and parameters of frequency of Legionella in warm water systems of hospitals and hotels in Lower Saxony. Zbl Bakt Hyg B 1988; 186: 79-88.

15. Boschek HJ, Langer BK, Exner M. Vorkommen von Legionellen in Warmwasserversorgungssystemen von Krankenhäusern und Pflegeheimen einer deutschen
Großstadt [Abstract]. Zbl Hyg Umweltmed 1995; 197 : 314-5.

16. Marrie T, Green P, Burbridge S, et al. Legionellaceae in the potable water of Nova Scotia hospitals and Halifax residences. Epidemiol Infect 1994; 112: 143-50.

17. Lück PC, Schütz M, Helbig JH, Jatzwauk L. Konstanz und Variabilität von Legionella pneumophila-Populationen im Wassersystem eines Universitätsklinikums [Abstract]. Zbl Hyg Umweltmed 1995; 197: 317-8.

18. Lück PC, Leupold I, Hlawitschka M, et al. Prevalence of Legionella species, serogroups, and monoclonal subgroups in hot water systems in south-eastern Germany. Zbl Hyg Umweltmed 1993; 193: 450-60.

19. Verissimo A, Marrao G, da Silva FG, da Costa MS. Distribution of Legionella spp. in hydrothermal areas in continental Portugal and the island of Sao Miguel, Azores. Appl Environ Microbiol 1991; 57: 2921-7.

20. Ta AC, Stout JE, Yu VL, Wagener MM. Comparison of culture methods for monitoring Legionella species in hospital potable water systems and recommendations for standardization of such methods. J Clin Microbiol 1995; 33: 2118-23.

21. Meunier JR, Grimont PAD. Factors affecting reproducibility of random amplified polymorphic DNA fingerprinting. Res Microbiol 1993; 144: 373-9.

22. Tyler KD, Wang G, Tyler SD, Johnson WM. Factors affecting reliability and reproducibility of amplificationbased DNA fingerprinting of representative bacterial pathogens. J Clin Microbiol 1997; 35: 339-46.

23. Bansal NS, McDonell F. Identification and DNA fingerprinting of Legionella strains by randomly amplified polymorphic DNA analysis. J Clin Microbiol 1997; 35: $2310-4$.

24. Lawrence C, Reyolle M, Dubrou S, et al. Single clonal origin of a high proportion of Legionella pneumophila serogroup 1 isolates from patients and the environment in the area of Paris, France, over a 10-year period. J Clin Microbiol 1999; 37: 2652-5.

25. Riffard S, Presti FL, Vandenesch F, et al. Comparative analysis of infrequent-restriction-site PCR and pulsedfield gel electrophoresis for epidemiological typing of Legionella pneumophila serogroup 1 strains. J Clin Microbiol 1998; 36: 161-7.

26. Lawrence C, Ronco E, Dubrou S, et al. Molecular typing of Legionella pneumophila serogroup 1 isolates from patients and the nosocomial environment by arbitarily primed PCR and pulsed-field gel electrophoresis. J Med Microbiol 1999; 48: 327-33.

27. Grattard F, Berthelot P, Reyrolle M, et al. Molecular typing of nosocomial strains of Legionella pneumophila by arbitrarily primed PCR. J Clin Microbiol 1996; 34: 1595-8. 